\title{
Average years of life lost due to breast and cervical cancer and the association with the marginalization index in Mexico in 2000 and 2010
}

\section{Promedio de años de vida perdidos por cáncer de mama y cervicouterino según índice de marginación estatal en México, 2000 y 2010}

\begin{abstract}
Média de anos de vida perdidos por câncer de mama e câncer de colo uterino no México pelo índice de marginalização estadual, 2000 e 2010
\end{abstract}

Claudio Alberto Dávila Cervantes 1

Marcela Agudelo Botero ${ }^{2}$

1 Facultad Latinoamericana
de Ciencias Sociales, Ciudad
de México, México.
2Instituto Nacional de
Geriatría, Ciudad de México,
México.
Correspondence
M. A. Botero
Departamento de
Epidemiología Clínica,
Instituto Nacional de
Geriatría.
Periférico Sur No.2767,
Colonia San Jerónimo Lídice,
Delegación Magdalena
Contreras, Distrito Federal
(México). C.P. 10200.
marcela.agudelo@salud.gob.mx

Abstract

The objective of this study was to calculate average years of life lost due to breast and cervical cancer in Mexico in 2000 and 2010. Data on mortality in women aged between 20 and 84 years was obtained from the National Institute for Statistics and Geography. Age-specific mortality rates and average years of life lost, which is an estimate of the number of years that a person would have lived if he or she had not died prematurely, were estimated for both diseases. Data was disaggregated into five-year age groups and socioeconomic status based on the 2010 marginalization index obtained from the National Population Council. A decrease in average years of life lost due to cervical cancer (37.4\%) and an increase in average years of life lost due breast cancer (8.9\%) was observed during the period studied. Average years of life lost due to cervical cancer was greater among women living in areas with a high marginalization index, while average years of life lost due to breast cancer was greater in women from areas with a low marginalization index.

Breast Neoplasms; Uterine Cervical Neoplasms; Potential Years of Life Lost

\section{Resumen}

El objetivo fue calcular el promedio de años de vida perdidos por cáncer de mama y cáncer cervicouterino en México para los años 2000 y 2010. Se utilizaron registros de mortalidad del Instituto Nacional de Geografía y Estadística, de mujeres entre 20 y 84 años de edad. Se estimaron tasas específicas de mortalidad y el promedio de años de vida perdidos por ambos padecimientos, los cuales determinan los años que deberían haber vivido las personas que fallecieron, en relación con la esperanza de vida. Los datos se agruparon según el índice de marginación estatal del Consejo Nacional de Población del 2010. Se observó un descenso en el promedio de años de vida perdidos por cáncer cervicouterino $(37,4 \%)$ y un incremento de los años de vida perdidos por cáncer de mama (8,9\%). Las mujeres que viven en estados con un índice de marginación alto y muy alto perdieron más años de vida por cáncer cervicouterino, mientras que mujeres de áreas más desarrolladas perdieron más años de vida por cáncer de mama. Se evidenciaron variaciones por grupos de marginación estatal y tipos de cáncer.

Neoplasias de la Mama; Neoplasias del Cuello Uterino; Años Potenciales de Vida Perdidos 


\section{Introduction}

The analysis of levels and trends of mortality not only serves as an important tool for health and social policy planning, but also highlights the heterogeneity of living conditions in different populations. Mortality can be a subtle indicator of the general socioeconomic and health characteristics of individuals $1,2,3$.

Several techniques exist for analyzing mortality (crude mortality, age-specific rates, life expectancy at birth), but none of these is capable of detailing aspects related to level and rate of change 4 . In Mexico, most epidemiological and demographic studies have used the aforementioned indicators to show the current picture of mortality. These studies show that the country has recently experienced a change in the rate and patterns of deaths, consisting of a reduction in deaths due to communicable diseases combined with a progressive increase in deaths due to chronic and degenerative diseases 5,6.

In 2000, the number of total deaths reported in Mexico was 437,667. Three main causes (cardiac disease, diabetes and malignant tumors) were responsible for $45.5 \%$ of this total. In 2010 , these conditions accounted for $49.7 \%$ of the total number of registered deaths $(592,018)$ and cardiac disease continued to be the leading cause of death, followed by diabetes and malignant tumors (Dirección General de Información en Salud, Secretaría de Salud. Defunciones 19792010. http://dgis.salud.gob.mx/cubos/, accessed on 16/Apr/2013).

In 2000, malignant tumors accounted for $14.8 \%$ of female deaths compared to $10.8 \%$ in males, while in 2010 these proportions were $13.8 \%$ and $10.4 \%$, respectively. Breast cancer and cervical cancer were the two leading causes of death within this category among women aged 25 years or over (Dirección General de Información en Salud, Secretaría de Salud. Defunciones 1979-2010. http://dgis.salud.gob.mx/cubos/, accessed on 16/Apr/2013). Historically, these two conditions have been the leading causes of death among women in this age group. The number of registered deaths due to breast cancer has showed an upward trend and surpassed cervical cancer in 2006 7,8.

The standardized cervical cancer mortality rate dropped between 1990 and 2010, from 28.7 deaths per 100 women to 14.6 , while the breast cancer mortality rate increased from 14.9 to 18.7 deaths per 100 women. It has been argued that the decrease in the cervical cancer mortality rate is due to intensive prevention campaigns, women's health education and increased use of Pap smear screening tests, and, until recently, the relative neglect of breast cancer ${ }^{9}$. However, this remains an important topic for further research.

Several studies of these two pathologies have shown problems connected to gender-related barriers to accessing health care and quality of care 9,10,11,12,13. In Mexico, disparities in mortality rates still exist related to socioeconomic and geographic factors and the study of these variables is therefore important to obtain a better understanding of cervical cancer and breast cancer mortality 7,9,14,15.

The main objective of this study was to analyze the association between cervical cancer and breast cancer mortality in Mexico and the marginalization index. We calculated years of life lost (YLL) for 2000 and 2010 and compared changes between the two periods.

This research received no funding.

\section{Methods}

This is a comparative cross-sectional descriptive study using nationally representative mortality data from 2000 and 2010 obtained from the National Institute for Statistics and Geography (INEGI) and the Directorate General for Health Information (DGIS) (INEGI. Mortalidad General. http://www.inegi.org.mx/est/contenidos/espa nol/proyectos/continuas/vitales/bd/mortalidad/ MortalidadGeneral.asp?s=est\&c=11144, accessed on 05/May/2013). Age-specific breast and cervical cancer mortality rates were calculated among women in five-year age groups (from 20 to 84 years). Data was selected based on the International Classification of Diseases, Tenth Revision (ICD-10 codes for breast cancer and cervical cancer are C50 and C53, respectively) ${ }^{16}$. The following cases were excluded: (1) where age and sex was not specified; (2) deaths that occurred abroad; (3) women aged under 20 and over 85 years; and (4) breast cancer in males.

The total number of registered deaths from breast cancer and cervical cancer in 2000 and 2010 was 8,088 and 9,021, respectively, and the proportion of excluded cases was $10.3 \%$ and $12 \%$, respectively.

Since this investigation used data from secondary sources available in the public domain which do not identify sample members, it was not necessary to obtain ethical approval.

\section{Data analysis}

The age-specific breast cancer and cervical cancer mortality rates for the year 2010 were estimated based on the number of deaths registered 
for each five-year age group divided by the total population of women in the corresponding group.

YLL was calculated using Arriaga's method, which estimates how many years of life a population loses on the average, due to death at various ages and from different causes 4,17. Despite being one of the main tools for measuring changes in mortality rate 4 , this technique has seldom been used in Mexico. This technique is based on the assumption that those individuals who died would have lived until the upper age limit of the chosen interval. The calculation of YLL was based on life tables for women from the year 201018 .

The first step of Arriaga's method is to assume that deaths listed by cause of death in the abridged life tables maintain the same distribution as the registered deaths for each age group, so that:

${ }_{n} d_{x, j}={ }_{n} d_{x}\left(\frac{{ }_{n} D_{x, j}}{{ }_{n} D_{x}}\right)$

Deaths between the age group $x$ and $x+n$ lose as many years of life within that age group (between 20 and 84) as deaths from breast cancer and cervical cancer multiplied by the difference between the age group interval $n$ and the separation factor for deaths ${ }_{n} k_{x}$ plus the upper age limit $v$ minus the age $v$ and the age group $n$. Under a uniform distribution of death, the separation factor ${ }_{n} k_{x}$ is equal to 2.5 and therefore YLL of deaths due to cause of death $j$ between ages $x$ and $x+n$ is calculated as follows:

$\mathrm{u}, \mathrm{n} \mathrm{AP}_{\mathrm{x}, \mathrm{j}}={ }_{\mathrm{n}} \mathrm{d}_{\mathrm{x}, \mathrm{j}}\left[\left(\mathrm{n}-{ }_{\mathrm{n}} \mathrm{k}_{\mathrm{x}}\right)+(\mathrm{v}-\mathrm{x}-\mathrm{n})\right]$

Furthermore, the average years of life lost (AYLL) of individuals still living at the lower age limit due to cause $j$ (in this study BC or CC) between the ages $x$ and $x+n$ is calculated as follows:

${ }_{\mathrm{u}, \mathrm{n}} \mathrm{ap}_{\mathrm{x}, \mathrm{j}}=\frac{\left.{ }_{\mathrm{n}} \mathrm{d}_{\mathrm{x}, \mathrm{j}}\left(\mathrm{v}-{ }_{\mathrm{n}} \mathrm{k}_{\mathrm{x}}-\mathrm{x}\right)\right]}{\mathrm{l}_{\mathrm{a}}}$,

where $l_{a}$ is the number of people alive at the exact age $a$ of the life table.

AYLL due to cause of death $j$ in the age interval $u$ years is the sum of YLL between the ages $a$ and $v$ :

$\mathrm{u}_{\mathrm{j}}=\sum_{x=a}^{v} \mathrm{u,n} \mathrm{ap}_{\mathrm{x}, \mathrm{j}}$

\section{Stratified analysis}

This study also assessed the relationship between breast cancer and cervical cancer mortality based on YLL and socioeconomic status and analyzed differences between the two periods.
Socioeconomic status was estimated based on state marginalization indexes obtained from the National Population Council (CONAPO, acronym in Spanish. Índice de Marginación por Entidad Federativa y Municipio 2010. http://www. conapo.gob.mx/es/CONAPO/Indices_de_Mar ginacion_2010_por_entidad_federativa_y_mu nicipio, accessed on 24/Mar/2013). This index is based on the global impact of the disadvantages faced by the population as a result of inadequate housing, lack of access to education and health, and lack of basic necessities. The index is used to identify geographic inequalities and define priority areas for the implementation of focused programs. CONAPO classifies level of marginalization in five groups: very high, high, average, low and very low. To facilitate information handling and achieve a higher contrast between clusters, we chose to regroup these classifications into three categories (Figure 1): high (Campeche, Chiapas, Guerrero, Hidalgo, Michoacán, Oaxaca, Puebla, San Luis Potosí, Tabasco, Veracruz, Yucatán); average (Durango, Guanajuato, Morelos, Nayarit, Querétaro, Quintana Roo, Sinaloa, Tlaxcala, Zacatecas); and low (Aguascalientes, Baja California, Baja California Sur, Coahuila, Colima, Chihuahua, Distrito Federal, Jalisco, México, Nuevo León, Quinta, Sonora, Tamaulipas).

\section{Results}

In 2000 and 2010, overall AYLL among Mexican women aged between 20 and 84 year was 6.8 years. The percentage of overall AYLL due to breast cancer and cervical cancer in 2000 and 2010 was $4.9 \%$ and $4 \%$, respectively. In 2000 AYLL due to cervical cancer was higher than the AYLL due to breast cancer, but this situation was inverted in 2010.

AYLL due to breast cancer and cervical cancer changed between 2000 and 2010. During this ten-year period there was an $8.9 \%$ increase in AYLL due to breast cancer (0.138 in 2000, 0.154 in 2010) and a $37.4 \%$ decrease in AYLL due to cervical cancer (0.190 in 2000, 0.119 in 2010). Overall AYLL due to breast cancer and cervical cancer decreased from 31,800 to 26,145 during the period which represents a $17.8 \%$ decrease. A small change in AYLL due to breast cancer was observed among women in the 20 to 54 year age group. After 55 years, AYLL due to breast cancer increased, especially in women in the 60 to 69 year group. In both 2000 and 2010, AYLL due to breast cancer was greater among women in the 50 to 59 year age group. A decrease in AYLL was observed in the following age groups: 20 to 24 


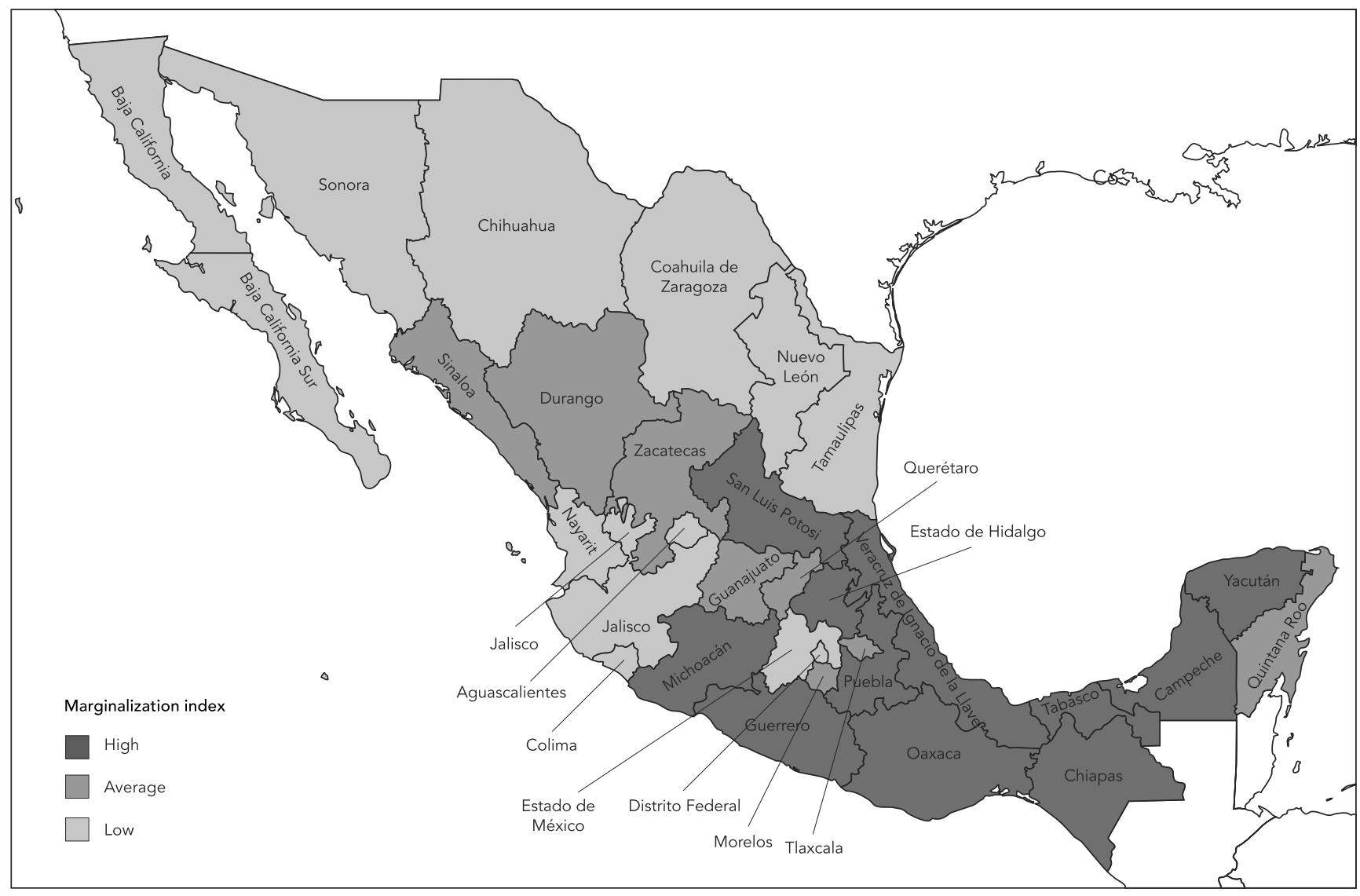

years (1.2\%), 30 to 34 years (10.7\%), 40 to 44 years (2\%), and 50 to 54 years (3.9\%) (Figure 2).

In contrast to the results for breast cancer, a decrease in AYLL due to cervical cancer was observed in all age groups, except the 20 to 24 year group, in which AYLL increased to $11.1 \%$. The decrease in AYLL among women in the 35 to 49 year and 75 to 84 year groups was greater than the national average. In 2000, AYLL due to cervical cancer was greatest in women in the 50 to 54 year age group, while in 2010 it was greatest in the 70 to 74 year age group (Figure 3). Breast cancer and cervical cancer mortality rates increased with age (Figures 2 and 3), and mortality due to breast cancer was constantly higher than mortality due to cervical cancer in all age groups.

With respect to deaths due to breast cancer in $2010,27.2 \%$ were in areas with high levels of marginalization, $60.8 \%$ were in areas with low levels of marginalization and $11.9 \%$ were in areas with average levels of marginalization. With regard to deaths due to cervical cancer, $40.6 \%$ were in areas with high levels of marginalization $47.6 \%$ were in areas with low levels of marginalization and $11.7 \%$ were in areas with average levels of marginalization.

The stratified analysis showed significant changes in AYLL due to breast cancer and cervical cancer between 2000 and 2010: there was a $16.4 \%$ increase in AYLL due to breast cancer in areas with high levels of marginalization, while in areas with average and low levels of marginalization the increase was only $8.5 \%$ and $6.6 \%$, respectively (Figure 4).

AYLL due to cervical cancer decreased in every marginalization category: average (42.2\%), high $(39.7 \%)$, and low $(35.2 \%)$. This is in contrast to AYLL due to breast and cervical cancer. In 
Figure 2

Age-specific death rates and average years of life lost (AYLL) due to breast cancer. Mexico, 2000 and 2010.
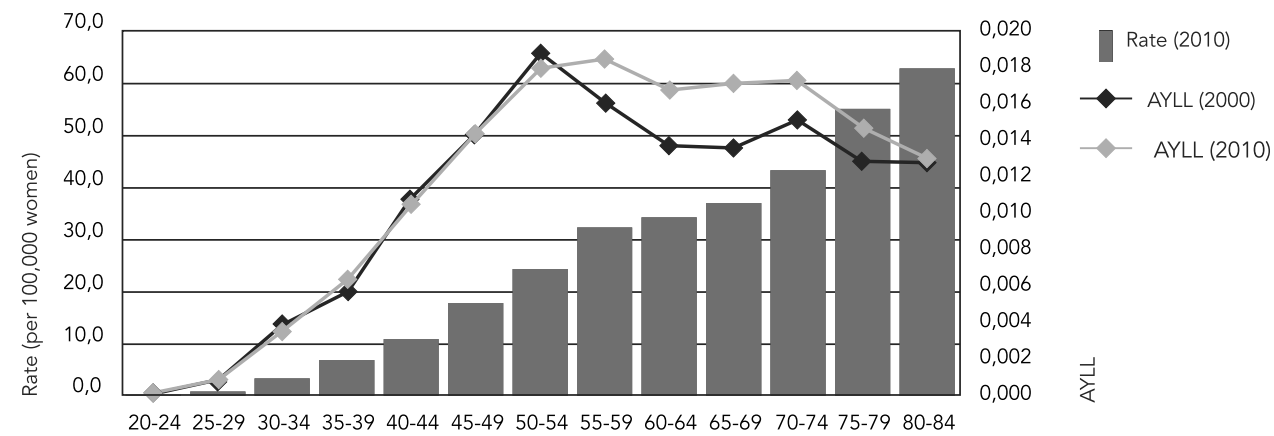

5 -year age groups

Source: elaboration based on vital statistics mortality data from the National Institute for Statistics and Geography and the Directorate General for Health Information (INEGI. Mortalidad General. http://www.inegi.org.mx/est/contenidos/espanol/ proyectos/continuas/vitales/bd/mortalidad/MortalidadGeneral.asp?s=est\&c=11144, accessed on 05/May/2013) and population estimates of the National Population Council (CONAPO. Índice de Marginación por Entidad Federativa y Municipio 2010. http://www.conapo.gob.mx/es/CONAPO/Indices_de_Marginacion_2010_por_entidad_federativa_y_municipio, accessed on 24/Mar/2013)

Figure 3

Age-specific death rates and average years of life lost (AYLL) due to cervical cancer. Mexico, 2000 and 2010.

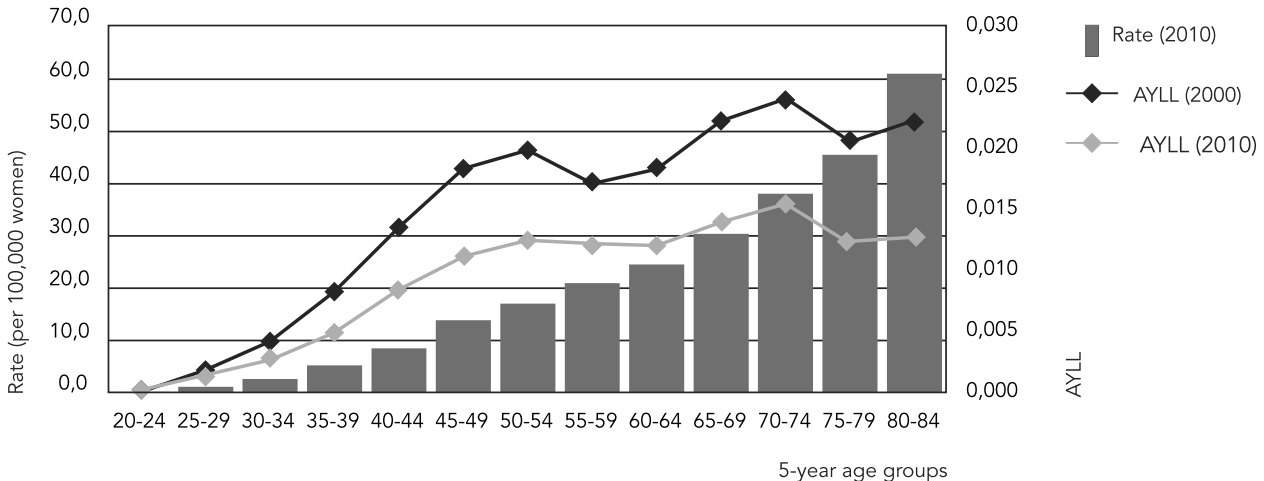

Source: elaboration based on vital statistics mortality data from the National Institute for Statistics and Geography and the Directorate General for Health Information (INEGI. Mortalidad General. http://www.inegi.org.mx/est/contenidos/espanol/ proyectos/continuas/vitales/bd/mortalidad/MortalidadGeneral.asp?s=est\&c=11144, accessed on 05/May/2013) and population estimates of the National Population Council (CONAPO. Índice de Marginación por Entidad Federativa y Municipio 2010. http://www.conapo.gob.mx/es/CONAPO/Indices_de_Marginacion_2010_por_entidad_federativa_y_municipio, accessed on 24/Mar/2013). 


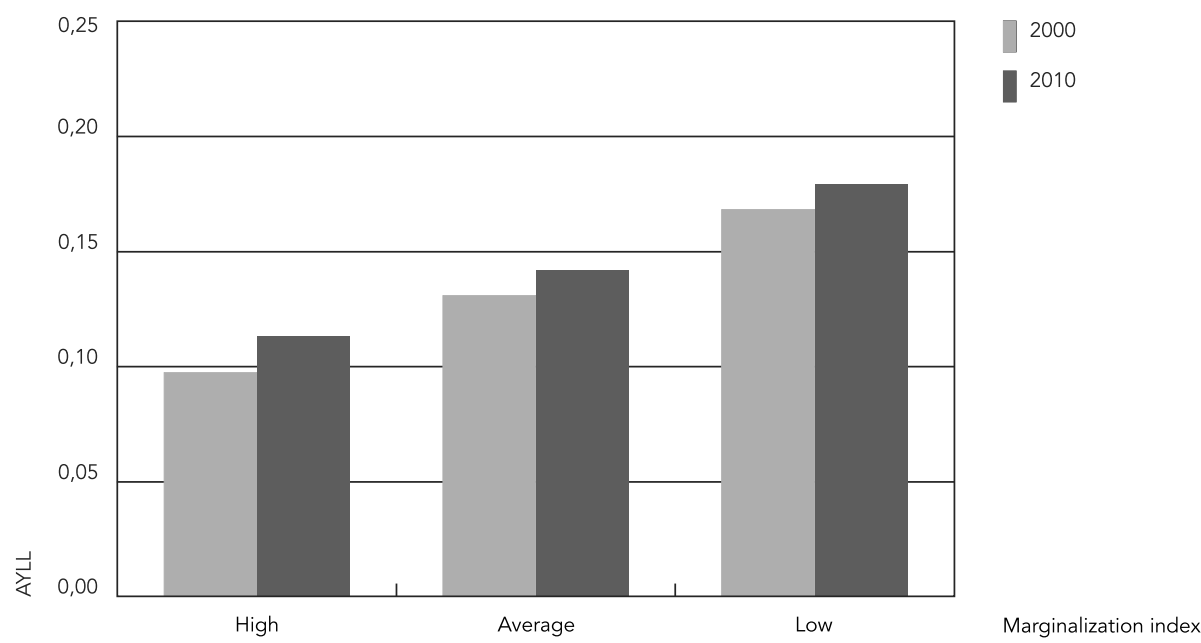

both 2000 and 2010 AYLL due to cervical cancer was greatest in the high level of marginalization category and lowest in the low level of marginalization category (Figure 5). Overall, we found that AYLL due to breast cancer increases with increasing socioeconomic status.

In 2000, AYLL due to cervical cancer was considerably greater than AYLL due to breast cancer in every category. In 2010, AYLL due to breast cancer was greater than AYLL due to cervical cancer in women living in areas with average and low levels of marginalization. Although cervical cancer ranks above breast cancer in areas with high levels of marginalization, rates are becoming increasingly similar, mainly due to a noticeable reduction in the number of deaths due to cervical cancer and a sustained increase in the breast cancer mortality rate (Figures 4 and 5).

\section{Discussion}

Diseases such as breast cancer and cervical cancer have devastating consequences for the life and health of Mexican women. A little over a third of the deaths caused by these neoplasms occur at a young age, generally before the age of 50 . The fact that death occurs at a young age (in contrast to what generally occurs with other chronic and degenerative diseases) 19,20,21 means that effective strategies must be developed to ensure timely detection and treatment.
Other studies have emphasized the positive impact on health of educating women about these conditions $21,22,23,24$. The fundamental goal of such programs is for women to understand that both breast cancer and cervical cancer are preventable and curable, if detected early $10,14,25,26$. Although data shows that YLL due to cervical cancer declined considerably between 2000 and 2010, it is crucial to continue and to strengthen actions directed at education, prevention and continuous monitoring of breast cancer. Socioeconomic disparities in Mexico shown by the different marginalization indexes, confirm the need for interventions adjusted to multiple lifestyles and living conditions 7,27,28,29. The trends in mortality from breast cancer cervical cancer and YLL observed by this study are consistent with findings of studies in other Latin American countries where mortality rates due to breast cancer have surpassed cervical cancer 30,31 .

Women who live in less developed areas encounter a number of problems, including major obstacles to getting timely access to healthcare, mistreatment by health professionals, cultural taboos and difficulties in paying for healthcare services (appointments, medications and treatment). Women living in rural or marginal urban areas often face geographical and transport barriers to accessing health centers, while those from ethnic groups (Afro-descendants and indigenous people) suffer discrimination and may 


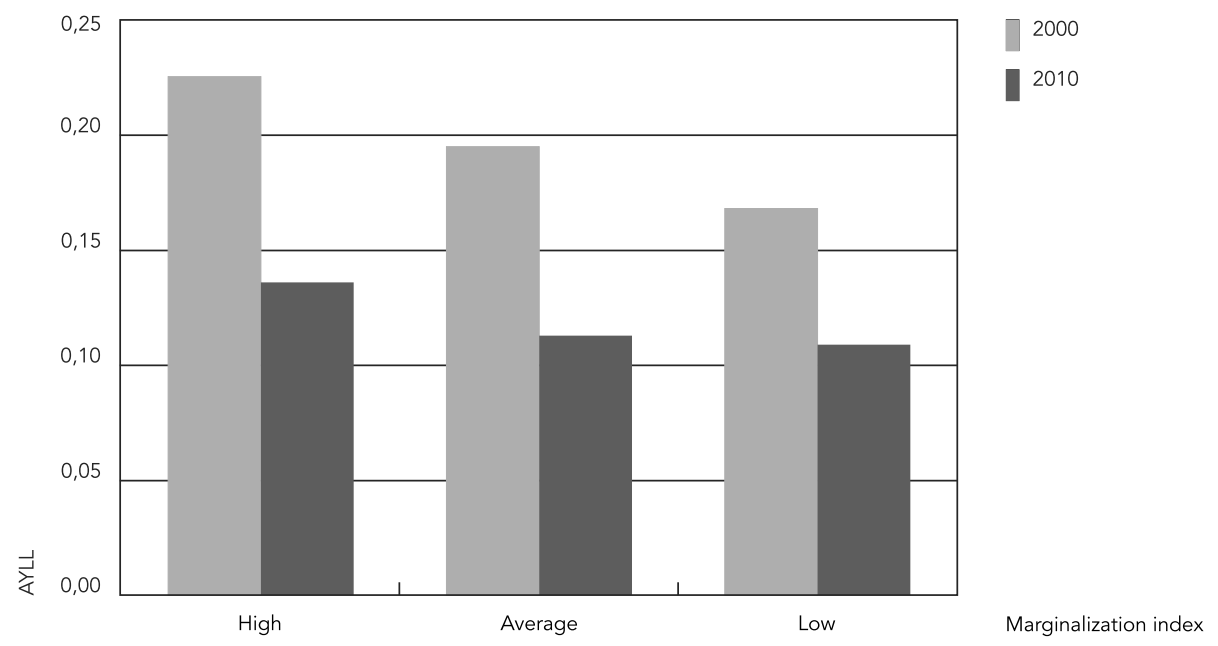

have limited fluency in Spanish, thus negatively affecting their chances of survival 1,2,3,9,32,33,34.

The results regarding breast cancer are similar to findings of other studies that observed that people living in more developed regions are at a greater risk of dying from breast cancer 10,30,31,35. Mortality from breast cancer in Latin America shows and increasing trend in several different socioeconomic groups 7,10,30,31 . Various studies have highlighted that women from the poorest sectors of society are less likely to use early detection screening techniques, such as breast selfexamination, clinical breast examinations and mammograms, resulting in later diagnosis and a less favorable outcome 36,37 .

One of the clearest reasons for the decrease in mortality and associated YLL due to cervical cancer in Mexico are programs aimed at prevention and early diagnosis reinforced with a permanent information campaign directed toward women and health professionals 9,15,38. Since breast cancer is a multi-causality condition, it is yet not precisely known which factors are associated with mortality variation. Some researchers argue that it is partly a consequence of better case reporting among women with access to health services, which leads to an underestimation of the effect of breast cancer in vulnerable populations 30 .

The use of YLL in this type of analysis provides a wide range of possibilities for measuring changes in levels and trends of mortality by age group. The use of YLL can enable greater preci- sion in the identification of vulnerable populations, improve focused targeting for programs and help make the best use of available resources. Socioeconomic disaggregation was used to understand breast cancer and cervical cancer behavior in two different years, helping to clarify the double burden that these diseases place on the healthcare system.

The main contribution of this empirical analysis is that it provides greater insight into an indicator which is underutilized in Mexico, allowing us to view mortality due to breast and cervical cancer in Mexican women from another angle. We recommend a permanent improvement in vital statistics, especially the uniform classification of causes of death, to allow calculations that are more attuned to reality.

\section{Limitations}

The main limitation of YLL is that it is necessary to delimit age ranges and therefore women outside the range (in this case, those over 84 years of age) are therefore excluded from the analysis 4,17. YLL is calculated using vital statistics data which suffer a number of limited including: lack of a uniform definition, omission errors, inadequate coverage in more isolated regions of the country, and underreporting of deaths 39 .

Another difficulty is that the information is derived from mortality records which do not 
register socioeconomic status. The socioeconomic status of subjects is therefore based on the marginalization index for the place of residence declared in the vital statistics. However, since this index is only a general measure for an area or region, and not specific measure of socioeconomic status of an individual, it would be erroneous to assume that a person residing in an area with a high marginalization index is necessarily poor. However, it is much more likely to find populations classified as poor in areas with a high marginalization index than in areas with a low marginalization index and so this index serves as a general measure for public policy targeting.

\section{Resumo}

O objetivo foi calcular a média de anos de vida perdidos por câncer de mama e câncer de colo uterino no México para os anos 2000 e 2010. Foram utilizados os registros do Instituto Nacional de Geografia e Estatística do México sobre a mortalidade das mulheres entre 20 e 84 anos de idade. Foram estimadas as taxas específicas de mortalidade e a média de anos de vida perdidos pelas duas condições, as quais determinam os anos que deveriam ter vivido as pessoas que faleceram, em relação à expectativa de vida. Os dados foram desagregados por grupos quinquenais de idade e de acordo com o índice de marginalidade estadual. Nos anos estudados, foi observado um declínio na média de anos de vida perdidos devido ao câncer de colo uterino $(37,4 \%)$ e um aumento de anos de vida perdidos devido ao câncer de mama (8,9\%). As mulheres que vivem em estados com um indice de marginalização alto e muito alto perderam mais anos de vida devido ao câncer de colo uterino, enquanto as que vivem em áreas mais desenvolvidas perderam mais anos de vida devido ao câncer de mama. Foram evidenciadas variações por grupos de marginalização estadual e pelo tipo de câncer.

Neoplasias da Mama; Neoplasias do Colo do Útero; Anos Potenciais de Vida Perdidos

\section{Practical implications}

The major contribution of this study is that YLL demonstrates the impact of breast and cervical cancer mortality among Mexican women, adding to relevant literature on these pathologies that shape the national epidemiological profile.

Our results highlight the need to develop diverse strategies for raising the awareness of these conditions, educating women and healthcare professionals and improving access to comprehensive health services (prevention, diagnosis, treatment, follow-up). It is essential to curb the current trend in mortality due to breast cancer and seek ways of countering the persistent inequalities between different regions in Mexico. Regarding cervical cancer, the task that remains is to ensure a further decrease in the number of deaths by continuing actions aimed at the most vulnerable segment of the population.

\section{Contributors}

C. A. D. Cervantes participated in study conception, data analysis and interpretation, drafting this article the critical revision of the manuscript for important intellectual content and final approval of the version to be published. M. A. Botero contributed to study conception, drafting this article, the critical revision of the manuscript for important intellectual content and final approval of the version to be published. 


\section{References}

1. Mustard CA, Etches J. Gender differences in socioeconomic inequality in mortality. J Epidemiol Community Health 2003; 57:974-80.

2. Braveman PA, Cubbin C, Egerter S, Williams DR, Pamuk E. Socioeconomic disparities in health in the United States: what the patterns tell us. Am J Public Health 2010; 100:186-96.

3. Vega WA, Rodríguez MA, Gruskin E. Health disparities in the Latino population. Epidemiol Rev 2009; 31:99-112.

4. Arriaga E. Comentarios sobre algunos índices para medir el nivel y el cambio de la mortalidad. Estudios Demográficos y Urbanos 1996; 11:5-30.

5. Frenk J, Bobadilla JL, Stern C, Frejka T, Lozano R. Elements for a theory of the health transition. Health Transit Rev 1991; 1:21-38.

6. Frenk J. Transiciones: vidas, instituciones, ideas. Salud Pública Méx 1997; 39:144-50.

7. Palacio LP, Lazcano E, Allen B, Hernández M. Diferencias regionales en la mortalidad por cáncer de mama y cérvix en México entre 1979 y 2006 . Salud Pública Méx 2009; 51:208-19.

8. Franco F, Lazcano E, López L. Breast cancer mortality in Mexico: an age-period-cohort analysis. Salud Pública Méx 2009; 51:157-64.

9. Nigenda G, Caballero MC, González LM. Barreras de acceso al diagnóstico temprano del cáncer de mama en el Distrito Federal y en Oaxaca. Salud Pública Méx 2009; 51:254-62.

10. Agudelo M, Dávila CA, Aguirre AF. Variaciones en los años de vida perdidos por cánceres de mama y cérvico uterino en México según grado de marginación estatal, 1997 y 2007. Rev Chil Salud Pública 2010; 14:8-17.

11. Anderson BO, Yip CH, Ramsey SD, Bengoa R, Braun $\mathrm{S}$, Fitch $\mathrm{M}$, et al. Breast cancer in limited-resource countries: health care systems and public policy. Breast J 2006; 12:54-69.

12. Sherris J, Herdman C, Elias C. Cervical cancer in the developing world. West J Med 2001; 175:231-3.

13. Loehrer PJ, Greger HA, Weinberger M, Musick B, Miller M, Nichols C, et al. Knowledge and beliefs about cancer in a socioeconomically disadvantaged population. Cancer 1991; 68:1665-71.

14. Knaul FM, Nigenda G, Lozano R, Arreola H, Langer A, Frenk J. Breast cancer in Mexico: a pressing priority. Reprod Health Matters 2008; 16:113-23.

15. Lazcano E, Palacio LS, Allen B, Yunes E, Alonso P, Schiavon R, et al. Decreasing cervical cancer mortality in Mexico: effect of Papanicolaou coverage, birthrate, and the importance of diagnostic validity of cytology. Cancer Epidemiol Biomarkers Prev 2008; 17:2808-17.

16. World Health Organization. International statistical classification of diseases and related health problems. 10th Rev. $2^{\text {nd }}$ Ed. Geneva: World Health Organization; 2004

17. Arriaga E. Los años de vida perdidos: su utilización para medir el nivel y cambio de la mortalidad. Notas Poblac 1996; 24:7-38.

18. Mina A. Funciones de sobrevivencia empleadas en el análisis demográfico. Papeles de Población 2001; 28:131-54.
19. World Health Organization. Preventing chronic diseases: a vital investment http://www.who.int/ topics/chronic_diseases/en/ (accessed on 15/Jun/ 2013).

20. World Health Organization. Noncommunicable diseases country profiles 2011. Geneva: World Health Organization; 2011.

21. Paskett ED, Tatum CM, D’Agostino Jr. R, Rushing J, Velez R, Michielutte R, et al. Community-based interventions to improve breast and cervical cancer screening: results of the Forsyth County Cancer Screening (FoCaS) Project. Cancer Epidemiol Biomarkers Prev 1999; 8:453-9.

22. Koval AE, Riganti AA, Foley KL. CAPRELA (Cancer Prevention for Latinas): findings of a pilot study in Winston-Salem, Forsyth County. N C Med J 2006; 67:9-15.

23. Austin LT, Ahmad F, McNally MJ, Stewart DE. Breast and cervical cancer screening in Hispanic women: a literature review using the health belief model. Womens Health Issues 2002; 12:122-8.

24. López L, Torres L, López M, Rueda C. Identificación de lesiones mamarias malignas en México. Salud Pública Méx 2001; 43199-202.

25. Anand P, Kunnumakara A, Sundaram C, Harikuma $\mathrm{KB}$, Tharakan S, Lai O,et al. Cancer is a preventable disease that requires major lifestyle changes. Pharm Res 2008; 25:2097-116.

26. Key TJ, Schatzkin A, Willett WC, Allen NE, Spencer EA, Travis RC. Diet, nutrition and the prevention of cancer. Public Health Nutr 2004; 7:187-200.

27. Anderson BO, Braun S, Carlson RW, Gralow JR, Lagios MD, Lehman C, et al. Overview of breast health care guidelines for countries with limited resources. Breast J 2003; 9:42-50.

28. González LM, González MC, Nigenda G, López L. Acciones gubernamentales para la detección temprana del cáncer de mama en América Latina: retos a futuro. Salud Pública Méx 2010; 52:533-43.

29. Palacio LP, Rangel G, Hernández M, Lazcano E. Cervical cancer, a disease of poverty: mortality differences between urban and rural areas in Mexico. Salud Pública Méx 2003; 45 Suppl 3:315-25.

30. Lozano R, Gómez H, Lewis S, Torres L, López L. Tendencias del cáncer de mama en América Latina y el Caribe. Salud Pública Méx 2009; 51 2:147-56.

31. International Agency for Research on Cancer. GLOBOCAN 2008: cancer incidence and mortality worldwide. http://www.iarc.fr/en/media-centre/ iarcnews/2010/globocan2008.php (accessed on 18/Jun/2012).

32. Unger $\mathrm{K}$, Infante $\mathrm{CB}$. Breast cancer delay: a grounded model of help-seeking behaviour. Soc Sci Med 2011; 72:1096-104.

33. Cuthbertson SA, Goyder EC, Poole J. Inequalities in breast cancer stage at diagnosis in the trent region, and implications for the NHS Breast Screening Programme. J Public Health 2009; 31:398-405.

34. Bharel M, Casey C, Wittenberg E. Disparities in cancer screening: acceptance of Pap smears among homeless women. J Womens Health 2009; 18:2011-6. 
35. Porter P. Global trends in breast cancer incidence and mortality. Salud Pública Méx 2009; 51:141-6.

36. Knaul F, Bustreo F, Ha E, Langer A. Breast cancer: why link early detection to reproductive health interventions in developing countries? Salud Pública Méx 2009; 51:220-7.

37. Anderson BO, Braun S, Lim S, Smith RA, Taplin S, Thomas DB. Global Summit Early Detection Panel: early detection of breast cancer in countries with limited resources. Breast J 2003; 9:51-9.
38. Lazcano E, Allen B. Innovation in cervical cancer prevention and control in Mexico. Arch Med Res 2009; 40:486-92.

39. Lozano R. Es posible seguir mejorando los registros de las defunciones en México? Gac Méd Méx 2008; 144:525-34.

Submitted on 11/Jun/2013

Final version resubmitted on 19/Oct/2013

Approved on 04/Nov/2013 